\title{
The stony road we tread: The challenges and contributions of Black Liberation Theology in post-apartheid South Africa
}

\section{Itumeleng Daniel Mothoagae ${ }^{1}$}

\begin{abstract}
The Great Trek of 1838 brought about a belief in the supremacy of the Dutch descendants in South Africa. Their 1948 election victory authenticated for them their interpretation of theology and their historical experiences of God's involvement in their lives. Black Theology challenged the perception of Afrikaner supremacy and their theological hegemony, although Mosala argued against the blindness of black theologians in their criticism of "white theology" because they were actually using the same tools of analysis that whites had traditionally used to justify their case (Mosala and TIhagale 1986:175-196). Mosala .
\end{abstract}

This article discusses a paper presented at a conference in Cairo by Takatso Mofokeng on the issue of land, and further outlines the challenges and contributions of Black Theology today.

Keywords: Interpretation, White Theology, land, Black Liberation Theology.

\section{Introduction}

According to Parratt (1990:528), "[F]or the first generation of black theologians, however, the definition of 'black' was not narrowly racist, it was rather a synonym for oppression, for those who were deprived of their rights". In a similar vein, Motlhabi (2008:23) argues that the agenda for Black Theology was the discovery of the original Christian teaching, in other words, the message behind the distorting tendencies of "white theology". What we can deduce from Motlhabi is that Black Theology in essence interprets the gospel of Christ in the light of the black condition. This article will focus on the challenges and relevance of Black Theology, and will outline the theology of Mofokeng on the issue of land and his contribution to Black Theology. It will conclude by drawing from the aspects in which Black Theology could contribute to the issue of land redistribution in South Africa, as well as the challenges that the South African democracy could be facing .

\section{The developments and challenges of Black Theology in South Africa}

One can begin to trace the development of Black Theology in South Africa from the founders of the liberation movements. This view is also held by

1 Itumeleng Daniel Mothoagae is a lecturer at the Department of Biblical and Ancient Studies, University of South Africa. He can be contacted at mothodi@unisa.ac.za. 
Kretzschmar (1986:3): "It is clear that black Christian leaders were at the forefront of African nationalist movements", and at the core of their ideologies was the theological interpretation of human dignity. Perhaps it was because of the 1838 theological interpretation of the superiority of the settlers at that time, and that God has ordained it for black people to be ruled and oppressed. One other supposition could be that, having studied what they hoped would allow them to claim the same space as their white counterparts, they still felt like inferior subjects of the superior race.

One of the earliest accounts of Black Theology and its challenges was by the Methodist Church minister Mangena Mokone. He observed that his own church was not practising what it taught - a rude awakening for him. Although all were Christians and brothers and sisters in Christ, at the same time there was a clear distinction between white and black in the Methodist Church. Mokone realised that "the African missionary was obliged to submit to the European missionary, on all points of issues" (Balia 1991:70). Mokone also saw a deep distinction regarding privileges that were enjoyed by white ministers and were denied to black ministers. He attests to the following regarding the treatment that black preachers received from white preachers:

The African preacher could no longer sit with his white brethren in the same gathering. The native preacher was to have his own Black conference where he and his kind could convene and always report proceedings for approval or rejection. On calling on his white brother, the native preacher could no longer enter by the front door as the back entrance had to be good enough for him, no matter what the nature of the business (Balia 1991:70).

Perhaps the apex of such theological interpretation was the official doctrine of the apartheid system, which divided people and taught that all were made different and some were created to be slaves. This view is also held by Bax (1983:118):

The report interprets God's reaction to this sin as reasserting His original command that mankind should split up into different volke with different languages and therefore different cultures. Moreover it adds that in re-establishing this process of differentiation God now extended it by dividing mankind into different races as well.

This view is further illustrated by Nicolson (1990:208), that apartheid, in effect, if no longer then official policy, in practice evaluated a person in terms of race. In other words, it said that black human beings were not as human as whites. It was for this reason perhaps that Mokone wrote a letter to the superiors in the Methodist Church in 1892, outlining what he regarded as an injustice and unchristian to the core. Mokone raised fourteen grievances, which led to his resignation and the forming of his own Ethiopian Church on 20 November 1892 (Balia 1991:71-73). 
Perhaps this theological view emerged from the dualism of body and soul, which to a great extent finds its unique and tragic expression in the experience of black people in South Africa and further afield. This was also observed by Mokone in his letter to the authorities of the Methodist Church. Policies such as the segregation law and apartheid's theological teaching caused blacks to be viewed by their oppressors as being either "soulless bodies" or "bodiless souls". These two terms are borrowed from the African-American scholar Earl (cited in Ware 2002:10), who argues that "these misinterpretations of a slave's anthropological nature constitute the core theological and ethical problem of American slavery".

Earl further argues that as bodiless souls, blacks were, to a limited degree, regarded as human. Yet at the same time, they were viewed as soulless bodies because of such theological views. As soulless bodies, the humanity of blacks was denied altogether. Recall how Sara Baartman was taken from her country and stripped of her dignity as a human being, as well as her womanhood. Furthermore, the burning of the cornfields and the imposition of taxes on Africans were ways of making slaves out of blacks. Another illustration was cheap labour before and during the apartheid era. This caused blacks to be viewed as bodies only, as physical machines for the production of wealth. Such a view cannot permit a sense of moral obligation towards blacks, and even towards God, from the side of the whites for their mistreatment of blacks. This suggests that such theological views could have been based on the following teachings:

Slaves were taught it is God's design, as decreed by the Holy

Scriptures, that they (Blacks), as the sons and daughters of Ham, be servants of whites into eternity. The life of a hewer of wood and carrier of water was not to be thought of as a curse, however. Rather it was to be recognised as a blessing in disguise; God's means of providing a road to salvation for the pagan African (Ware 2002:9).

Furthermore, teachings such as Genesis 11, the story of Babel, were used to cement the theology of racial differences, as well as the use of Acts 17:26 to support it is a interpretation of Genesis 1:28. In other words, it was the idea that, in spite of the common origin of humanity, the question of diversity has always been implicit in the creation story (Bax 1983:130). The foundation of the theology of apartheid was precisely to inculcate in the minds of blacks that they are sons and daughters of Ham. Though they may need educational training, theirs ought to be different from that of the superior race (the result was Bantu education) because they were different and they did not deserve to live and occupy the same space as the master. It could be suggested that the creation of Bantustans was to decree that. They had no privileges as citizens in their own country. This illustrates the slave and master relationship dynamics. These and many other reasons led to the theological interpretations that one would call the formation of "Black Theology". One of the questions 
that one might pose is: was the emergence of Black Theology a response to the so-called Christian teaching regarding Africans and their traditions, or did the reasons for its emergence lie deeper than that?

Kretzschmar (1986:1) offers the following regarding African Theology, Black Theology and Liberation Theology: "Black Christians have for a long time been speaking out concerning the church and related socio-economic and political issues." According to her, as stated above, the quest for the theological interpretation of human dignity from the African perspective has been on the table for a long time. It was for this reason that she further states that the formation of African Indigenous Churches points to, among many other reasons, the dissatisfaction with the white-dominated churches and the need to express their Christian faith in ways compatible with African traditional life (p. 2). The challenge of Black Liberation Theology was its relevance to society, firstly because the Christian faith was not a private affair; secondly, because the it was a faith that equipped them to meet the challenges of society that they had to face at that time; and, thirdly, because it was a faith that had to be applied to the conditions of their lives. Such an approach enabled black theologians to interpret and understand what it meant to be a Christian in the light of the gospel, as well as their own existential experiences. As a result, they managed to challenge the theological ideologies of that time. In this way, they became the forerunners of modern Black Theology.

\section{Black Theology, black consciousness and the quest for liberation}

Nicolson's observation (1990:201) regarding the emergence of Black Theology differs from that of Kretzschmar, in the sense that his point of departure is "black theology in South Africa emerged as part of the black consciousness movement that arose to fill the vacuum left after the banning of the African National Congress and the Pan African Movement in 1960". He further argues that "Black consciousness has provided a very important context for developing a theological hermeneutic. It has challenged black theologians to take seriously the particularity of the black experience." (Nicolson 1990:201).

While Kretzschmar addresses the notions of "Black Theology" and "black identity", she touches on the role of African Christian leaders as forerunners of such a theology, unlike Nicolson. Nicolson draws attention to the different methodologies adopted by the older generation of theologians, such as Tutu, Boesak, Maimela and Buthelezi, and the newer generation, such as Chikane, Mosala, Tlhagale and Mofokeng. Yet at the same time, he also takes into consideration the commonality between the two schools:

What they all have in common with liberation theology, however, is an insistence that God has a special concern for the oppressed, and 
that since salvation is concerned with the wholeness of life, oppression. The demands of the Christian gospel "are incompatible with unjust, alienating, and polarizing social arrangements". A purely spiritual gospel is alien to an African idea of the wholeness of life (Nicolson 1990:203).

The above citation has hermeneutical implications precisely because a clear distinction was advocated, namely between reading a text for a spiritual purpose and a contextual reading of the text. It was in applying the latter that black people came to the bible, with the Christian tradition from their own history, culture and situation. Thus they interpreted the bible and tradition in the light of the above and, at the same time, they allowed "the Bible to be a normative point of reference in understanding how to find liberation from the confines of the situation - thus the hermeneutic circle" (Nicolson 1990:204).

\section{The bible equals the dispossession of land: Contributions of Black Liberation Theology}

As indicated in the abstract, part of this article focuses on one of the black South African theologians, namely Takatso Mofokeng. This article will be limited to the paper that he presented at a conference in Cairo in 1987. Mofokeng's point of departure (1988:34) is as follows: "When the white man came to our country he had the bible and we had the land. The white man said 'let us pray'. After the prayer, the white man had the land and we had the bible."

Mofokeng points out in the above quoted statement that there are three dialectically related realities, namely the central role of the bible in the ongoing process of colonisation, national oppression and exploitation. Secondly, the statement expresses the incomprehensible paradox of being colonised by Christian people on the one hand and being converted to the masters' religion on the other hand and accepting the bible, which was their colonial instrument of oppression and exploitation. Lastly, it also expresses a historic solemn commitment accepted by one generation to the next. This commitment was to terminate disinheritance and eradicate exploitation of human beings by another (Mofokeng 1988:34).

Mofokeng further attests to the fact that colonialism was successful also because of its partnership with the Christian missionary enterprise. However, one must not imagine that this partnership was an enterprise from which only one benefited. According to Mofokeng (1988:34-35), the use of colonialism by the Christian missionary enterprise succeeded in two things: They reached their destination with the Bible, which is the religious heart of Africa, emptied it of all the "evil" contents that led to violent African social structures, corrupt political institutions and the weak economic 
system. Consequent to their activities the African people have accepted the new religion and the Bible as a guide in their lives. They have been introduced to new European cultural values, norms and attitudes and their entire society has been changed.

Muzorewa (cited in Mofokeng) asserts a similar argument to that of Mofokeng, namely that the partnership between colonialism and the Christian missionary enterprise was an indisputable fact. The colonists tended to utilise the missionaries to make their work easier. As a result, argues Muzorewa, there was a thin line between the missionary intention and the colonisation intent; this was because of the similarity of their goals (Mofokeng 1988:35).

Magubane, according to Mofokeng (1988:35), takes this idea even further by arguing forcefully that "the initial act of conquest was buttressed and institutionalised by ideological activities". In other words, because the conquest was reinforced and institutionalised through ideological activities as cited above, the African people themselves admitted the hegemony of the colonisers that embedded their culture. Magubane further asserts that "it was necessary for the Africans to be incorporated into the mental and cultural universe of their white conquerors through an ideological onslaught" (Mofokeng 1988:35). From the above citation, it seems undoubtedly true that the Christian missionaries, armed with the bible on the colonial ox wagon, were present when the wheels rolled violently through the length and breadth of the African continent.

Mofokeng outlines the three responses of the black people to this enterprise. He firstly points out the heroic defence of the legitimacy of African traditional religions and their hegemonic domains. According to him, these religions lost the struggle for exclusive ideological and spiritual control of the black communities. Secondly, because they lost this control, the African Indigenous Churches emerged as churches of compromise. In these churches, argued Mofokeng (1988:36), there were two elements that were synergised, namely the Christian tradition presented by the bible and traditional religion as conveyed by African oral tradition. The third response that he touches on is "that the colonial churches which represent the total surrender of African ideological field and a consequent total assimilation into European Christendom mushroomed as blacks were converted into them".

Mofokeng (1988:37) presents another element of the bible, that of paradox. In other words, he suggests that the bible presents us with both problems and solutions. It is for this reason that, according to him, this paradox is not only inherent but also external. The external paradox consists of issues such as racist oppression and the exploitation of black people by white people, which in itself presents a religious paradox. This observation by Mofokeng, that the forbearers of today's white Christians used the bible 
to assert and justify white supremacy and the right of whites to be masters over blacks, has been internationally recognised.

In South Africa, this use of the bible to exploit and justify such activities was manifested by theological interpretations of the 1838 Battle of Blood River, which was interpreted as a theological justification for the apartheid system. It resulted in the misuse of the bible by oppressor preachers. At the same time, Africans have tried to challenge this commonly held approach, maintaining that the oppressor preachers misinterpreted the biblical texts to suppose and promote oppressive intentions. According to Mofokeng (1988:39), the challenge by black theologians against such misinterpretations of the biblical texts led to "the dawning of the consciousness thrust by Black theologians into the centre of what Harvey Cox calls the 'age-old hermeneutical struggle' which is a struggle to resist and contest the interpretation of scripture by theologians who represent Christians of the dominant race and political order".

While this has been the enterprise of Black Theology, the challenge has been the epistemological break required, as well as the methods that could be employed, precisely because of the enslavement to the hermeneutical yoke of the West. As a result, many black theologians slipped back into using the dominant liberal hermeneutics. This backward slip, according to Mofokeng (1988:39), confirms the assertion by Anthony Mansueto that "existential or religious commitment to social revolution will substitute for scientific analysis of the valence of a tradition in the class struggle".

Mofokeng considers this as one step forward and two steps back in the hermeneutical area, and as a serious call for hermeneutical vigilance on the part of the entire community of black theologians. This will lead to what Mafeje (cited in Mofokeng 1988:39-40) regards as a "clear identification of issues (including theological issues)", which "is as important as fighting in the streets or in the mountains".

Mofokeng advocated a hermeneutics for the liberation of the bible. He argued that it was an open secret that black people have, ever since the bible was brought to them, asserted their rights to appropriate and interpret it in accordance with their socio-economic, cultural and religious needs. In seeking analytical tools that may be helpful in the search by black Christians for hermeneutical links in the bible as members of a silenced, marginalised and sometimes ignored race, black theologians discovered such people in the bible and developed an affinity with them. They further discovered a text behind the text of the bible. Such a discovery, argues Mofokeng (1988:41), constituted the liberation of the bible from the clutches of the dominant in the Christian fold who imposed the stories that they interpreted as justifying their victories over the oppressed. This view of Mofokeng is supported by Vorster in his analysis of the bible and apartheid. Vorster (1983:102) argues that "both its hermeneutic principles and the pretension that it offers a scientific 
exposition must be called into question". Furthermore, he asserts that the use of Genesis 10 and 11:1-9 to affirm and determine the diversity of people as according with the will of God and to affirm that it was God's intention from the beginning to differentiate the human race was a selective use of the bible. The use of the bible to justify the injustices of apartheid was a grid through which the bible was read. It was this grid, argues Vorster, that provided the hermeneutical key for a selective reading of the bible. As a result, there was no objective reading of the bible (p. 97).

\section{Stony the road we tread: Liberation without land. Relevance of Black Theology}

It can be argued that liberation and land are interrelated. Perhaps a question could be: is this reality or a dream in the context of post-apartheid South Africa? One of the evident issues regarding land is that one cannot engage in such a discourse without first engaging the question of race. Land, race and slavery are interconnected. After eighteen years of democracy, some may ask, is there a need for Black Theology? If so, what is its relevance to society today? One may suggest that in the past the core business of Black Theology was to challenge the theological ideologies that sought to isolate black people psychologically from participation as equals with their white counterparts. While there may be those who would argue that such a cause has been realised, the question still remains: is it a dream or a reality? It is for this reason that Black Theology in South Africa still has to engage with issues such as land, democracy, timocracy, race, corruption, and liberation. For Black Theology to be relevant, the point of departure should be "deconstruction" and "hermeneutics of restoration". These terms are borrowed from Evans (cited in Ware 2002:33). According to him, "deconstruction is both iconoclastic and constructive, dismantling intellectual systems for the purpose of exposing new possibilities for thought" (Ware 2002:33). In other words, it is both a project of iconoclasm and a project of retrieval. Deconstruction (hermeneutics of suspicion) implies questioning theories and suppositions that seem to suggest that we have found equality and political freedom. As a result, all other issues would then become apolitical and irrelevant, including the issue of land. Hermeneutics of restoration would address the issue of land and the impact of slavery in South Africa. This is because slavery has taken place in South Africa and one cannot claim to be liberated while one does not own the land. Yet at the same time, the question of who should own the land ought to be discussed as well. This is precisely because those who are the so-called freedom fighters seem to think that the country owes them and as a result policies such as "willing buyer, willing seller" do not serve the masses but the few.

Black Liberation Theology's discourse on deconstruction (hermeneutics of suspicion) and its hermeneutics of restoration continue to 
be relevant, as in the past when its point of departure was scrutinising European theology and utilising the experiences of black people for theological construction. In other words, Black Theology can continue to be relevant and contribute to theological discourse through its ongoing engagement with the socio-political and socio-economic issues of the post-apartheid society by applying such methods rather than being a critical care-taker. This view is taken up by Motlhabi (2008) on critical solidarity with the state. Maimela (cited in Mothoagae 2011:127) suggests that Black Theology "will play an important role in the future because there will always be elements in society who, for a variety of reasons, will feel themselves deprived, somehow oppressed and therefore in need of liberation, be it political, economic or socio-cultural". What Maimela seems to attest to is the fact that the above-cited Black Theology will continue to be relevant for as long as there are people from the previously marginalised group who experience the above deprivations.

One can argue that there seems to be a culture of silence that is permeating our scholarship and, as a result, the question of relevance continues to haunt us. It is for this reason that Motlhabi (cited in Mothoagae 2011:128) urges and challenges us against "critical solidarity with the state that black theologians seem to have taken by their silence". Perhaps one of the contributing factors to this silence is what Tshaka and Makofane (2010:544) refer to as the "elitist character of Black Theology". Motlhabi (cited in Mothoagae 2011:128) maintains that such solidarity with the state is dangerous if allowed to degenerate into a blind and uncritical following of the state in everything. Such solidarity affirms and sustains assumptions that we have made it, that all that we have fought for has been attained. Furthermore, the crucial issue with which Black Theology needs to engage is the observation made by Tshaka and Makofane (2010:545) that "the problem with guerrilla initiatives is that they are usually susceptible to the seduction of power". Perhaps the question that needs to be asked is "can a critic be a caretaker too"? (Omer 2011). It is for this reason that Black Liberation Theology will have to struggle with the same question repeatedly for as long as there is an injustice in the country.

\section{Conclusion}

This article began by outlining the misinterpretation of the bible by the historical events of 1838, as well as the 1948 victory of the white Afrikaner people. The 1948 election victory authenticated their interpretation of theology and their historical experiences of God's involvement in their lives. Black Theology became a vehicle for challenging such views. The article has discussed the developments and challenges of Black Theology in South Africa. One of the issues that Black Theology reflected on was liberation. The article has considered the contribution of Black Theology, 
particularly concerning the issue of land according to Mofokeng. Eighteen years into democracy, this issue is still being debated. Mofokeng maintains that the issue of land cannot be isolated from the role that the bible played in the dispossession of land from the people. The article has argued that the relevance of Black Theology today, among other things, is to question and challenge the issues of land and race in South Africa not in isolation, but in its wholeness. In other words, the challenge of Black Theology in the twenty-first century is to use its own methodologies, such as African proverbs, so to be able to re-read African slave writings through the lens of Black Theology and, furthermore, to attempt to show a link between the issue of land and slavery. This will enable us black theologians to engage critically with the land issue within the paradigm of liberation.

\section{References}

Balia, D.M. 1991. Black Methodists and white supremacy in South Africa. Durban: Madiba Publications.

Bax, D. 1983. The bible and apartheid 2, in Apartheid is a heresy, edited by J.W. De Gruchy and C. Villa-Vicencio. Cape Town: Lutterworth Press:112--143.

Kretzschmar, L. 1986. The voice of Black Theology in South Africa. Braamfontein: Ravan Press.

Omer, A 2011. Can a critic be a caretaker too? Religion, conflict, and conflict transformation. Journal of American Academy of Religion 79(2), June :459-496

Mofokeng, T. 1988. Black Christians, the bible and liberation. Journal of Black Theology in South Africa 2(1), June:34-42.

Mosala, I.J. and Tlhagale, B. 1986. The unquestionable right to be free: Essays in Black Theology. Johannesburg: Skotaville Publishers.

Mothoagae, I. 2011. Identity as a social construct of empire: Then and now. Studia Historiae Ecclesiasticae 37(supp.), December:115-130.

Motlhabi, M. 2008. African Theology/Black Theology in South Africa: Looking back, moving on. Pretoria: University of South Africa Press.

Nicolson, R. 1990. A black future? Jesus and salvation in South Africa. Philadelphia, Pa.: Trinity Press.

Parratt, J. 1990. Marxism, Black Theology, and the South African dilemma. Journal of Modern African Studies 28(3), September:527-533.

Tshaka, R.S. and Makofane, M.K. 2010. The continued relevance of Black Liberation Theology for democratic South Africa today. Scriptura 105:532-546.

Vorster, W. 1983. The bible and apartheid 1, in Apartheid is a heresy, edited by J.W. De Gruchy and C. Villa-Vicencio. Cape Town: Lutterworth Press:94-111.

Ware, F.L. 2002. Methodologies of Black Theology. Cleveland, Ohio: Pilgrim Press. 